\title{
A HARMONIA ENTRE OS PODERES DA REPÚBLICA FEDERATIVA DO BRASIL E O ATIVISMO JUDICIAL BRASILEIRO
}

\author{
Ronny Max Machado ${ }^{*}$ \\ Osmar Fernando Gonçalves Barreto ${ }^{2 * *}$
}

Resumo: O presente artigo estuda a relação entre os poderes da República e o papel do ativismo judicial no Brasil. Em especial, busca apontar, por meio de levantamento bibliográfico, as características negativas acerca deste denominado protagonismo judicial, que por sua vez, ofenderia, em tese, um dos pilares da democracia, a tripartição dos poderes. Diante de tal estudo, chega-se à conclusão de que todo e qualquer excesso deve ser repudiado, uma vez que, isso ofenderia e comprometeria a democracia do País. O Poder Judiciário não deve esvaziar as ações que competem primordialmente ao parlamento ou ao executivo.

Palavras-chave: Ativismo Judicial. Tripartição dos Poderes. Neoconstitucionalismo. Democracia. Poder Judiciário.

\section{THE HARMONY BETWEEN THE POWERS OF THE FEDERATIVE REPUBLIC OF BRAZIL AND BRAZILIAN JUDICIAL ACTIVISM}

\begin{abstract}
This article studies the relationship between the powers of the Republic and the role of judicial activism in Brazil. In particular, it seeks to point, through a bibliographic survey, the negative characteristics of this so-called judicial protagonism, which in turn would offend, in theory, one of the pillars of democracy, which is the tripartition of powers. Faced with such a study, it is concluded that any and all excess must be repudiated, since this would offend and compromise the democracy of the country. The Judiciary should not empty the actions that are primarily the responsibility of parliament or the executive.
\end{abstract}

\footnotetext{
$1^{*}$ Graduado em Direito pela Universidade São Judas Tadeu. Especialista em Direito Civil e Processo Civil pela Escola Paulista de Direito. Especialista em Direito Constitucional e Direito Administrativo pela Escola Paulista de Direito. Especialista em Direito Ambiental Empresarial pelo Centro Universitário das Faculdades Metropolitanas Unidas. Mestre em Direito da Sociedade da Informação pelo Centro Universitário das Faculdades Metropolitanas Unidas - São Paulo. Estado de São Paulo. Brasil. ronnymaxm@yahoo.com.br

$2^{2 * *}$ Graduado em Direito pelo Centro Universitário das Faculdades Metropolitanas Unidas - FMU. Especialista em Direito Privado pela Escola Paulista da Magistratura - EPM. Mestre em Direito da Sociedade da Informação pelo Centro Universitário das Faculdades Metropolitanas Unidas - FMU. Advogado. Professor na graduação do Centro Universitário das Faculdades Metropolitanas Unidas - FMU - SP. Professor na pós-graduação da Faculdade de Franca - SP. Professor de EAD na pós-graduação do Estratégia Concursos - SP. Professor Tutor no curso para Exame da OAB do Damásio Educacional - SP. E-mail: osmarbarreto2@ @otmail.com.
} 
Keywords: Judicial Activism. Tripartition of Powers. Neoconstitutionalism. Democracy. Judiciary Power.

\section{INTRODUÇÃO}

No Brasil, temos um cenário posto em xeque e sob enormes discussões, que versa sobre a atuação inovadora no plano da interpretação das regras e princípios por parte do Poder Judiciário.

O debate busca demonstrar pontualmente características negativas acerca deste denominado protagonismo Judicial, que por sua vez, ofenderia em tese um dos pilares da democracia, a tripartição dos poderes.

Apresentado o tema e o cerne da discussão, se faz necessário adentrarmos em alguns contornos do assunto em pauta. Para isso, alguns questionamentos que, muito embora não tenham uma resposta objetiva e tangível por parte da doutrina nacional e estrangeira, nos levará a reflexões face à discussão aqui apontada.

Estas questões têm por objetivo delimitar a proposta do presente trabalho, ante a amplitude do tema que é estudado em inúmeros países, que também terá sua específica menção por parte de alguns autores internacionais.

Quem são os lesionados pelo Ativismo Judicial? Quem se beneficia com o protagonismo dos Juízes? A democracia é violada em razão deste fenômeno jurídico? A negativa do Poder Judiciário poderia reeducar os cidadãos brasileiros na busca pela efetividade de seus direitos?

Como dito, as respostas são dadas nas mais variadas dimensões e perspectivas, por motivos de tempo e lugar em que se deram tais ações judiciais proativas a serviço da tutela dos direitos fundamentais, mas colocando em questão a importância do respeito e harmonia entre os Poderes preestabelecidos por um Estado.

Sabemos que as críticas possuem variadas densidades, contudo tem como escopo central o argumento de que Ativismo Judicial seria uma usurpação da função legiferante do Estado, cabendo considerar até aqueles que sustentam que tal fenômeno seria a degradação do Direito como um todo. 
Neste contexto e na busca por respostas a fim de formar uma convicção própria sobre o tema, traçaremos, por meio do método de levantamento bibliográfico, uma apresentação sobre a tripartição dos poderes, a abordagem acerca do constitucionalismo, do fenômeno denominado neoconstitucionalismo e do ativismo judicial sobre os mais variados pensamentos da doutrina brasileira que tratam o tema, cada um ao seu modo, que podem e muito contribuir para o aclaramento destas indagações.

\section{O ATIVISMO JUDICIAL}

Um dos temas mais discutidos em Direito e, por sua vez, ponto central do presente trabalho é o ativismo judicial, que consiste no protagonismo dos juízes.

Para obtermos uma compreensão do tema, seus prós e contras, se assim podemos denominar os argumentos que o sustentam e que repudiam, traremos uma gama de entendimentos dos mais diversos operadores, estudiosos e cientistas do Direito de nosso País.

Muito embora, não nos propomos a fixar uma verdade do que seria o modelo ideal de atuação do Poder Judiciário, buscamos trazer opiniões consistentes para compreender efetivamente o tema.

Mauro Cappelletti, dentro do nosso contexto de separação dos poderes, assevera com cautela que, mesmo as dimensões do Estado tenham atingido proporções não antes imagináveis, é necessário que, cada Poder atue nos limites de suas esferas de competência em detrimento daquilo que ele considera como sendo rule of law, senão vejamos:

[...] verifica-se uma percepção generalizada, ao menos nos países ocidentais, de que, em nossa 'era de leis' - como o Deão Calabresi a denominou - é realmente uma salvaguarda valiosa o controle por um julgador independente, de um legislador cada vez mais onipresente, cujo papel no Estado moderno cresceu em dimensões sem precedentes, mais ainda se considerarmos que esse controle constitui a necessária "coroação" da rule of law (CAPPELLETTI, 1990, p. 73).

Ramos (2010) é dentre aqueles contrários a ideia do ativismo judicial, um dos que apresenta os mais consistentes argumentos. Em uma de suas obras, ele explana que o ativismo judicial seria o equivalente a uma jurisprudência criativa. 
O referido jurista trabalha a ideia da separação dos poderes como garantidora da manutenção e harmonia dentro do Estado Democrático, sendo que, qualquer desvio, deturparia tal contexto, senão vejamos: "Portanto, o princípio da separação dos poderes parte da identificação das principais funções a serem desempenhadas pelo Estado, para a consecução de seus fins, o que, à evidência, está sujeito a toda sorte de condicionamentos históricos [...]” (RAMOS, 2010, p. 113).

Em continuação a argumentação aqui apresentada o professor reforça o fato de que não cabe a um outro órgão atuar na esfera de competência, assim fica assegurada a independência de cada um dos poderes e que a seus funcionários são reservadas prerrogativas e garantias específicas para que isso não ocorra:

Em segundo lugar, propõe-se que essas funções sejam atribuídas a estruturas orgânicas independentes entre si, o que exige dotar-se cada urna delas de determinadas prerrogativas institucionais e os seus titulares de garantias funcionais, estando a eles vedada, por outro a participação em funções estranhas ao aparato orgânico a que se vinculam (RAMOS, 2010, p. 114).

Contudo, o autor não se limita a essa única crítica ao ativismo. Ele parte do embate contra a fragilidade do fenômeno do neoconstitucionalismo aqui estudado.

Além disso, prossegue o professor indicando que, inicialmente, em afronta ao marco histórico defendido pelos pensadores da corrente neoconstitucional onde teriam ocorrido mudanças significativas de paradigma, o que em sua concepção não ocorreu, senão vejamos:

A referência ao marco histórico do neoconstitucionalismo não revela nada que permita distingui-lo do constitucionalismo tout court, vale dizer, da proposta de se assegurar estabilidade (segurança jurídica) e dinamismo (liberdade) ao sistema político democrático, a partir de Constituições documentais e rígidas. O Estado constitucional de Direito consolidou-se em períodos históricos diversificados, em relação a cada sociedade política, usualmente coincidindo com a consolidação do próprio sistema político democrático, não existindo fundamento algum para se afirmar que se trata de um fenômeno simultâneo e de abrangência universal, contemporâneo às últimas décadas do século XX. Quanto ao marco filosófico, intitulam-se os neoconstitucionalistas de pós-positivistas, como se o positivismo jurídico, com as renovações por que passou e continua passando, tivesse deixado de ser o modelo dominante nos domínios da Teoria do Direito e, consequentemente, da Dogmática Jurídica [...]. Na verdade, os neoconstitucionalistas brasileiros são antipositivistas (e não pós-positivistas), mas preferem dedicar um epitáfio ao positivismo jurídico do que se afirmar em combate com essa variante teórica, que continua extremamente influente no campo da Ciência do Direito (mera estratégia deslegitimadora, portanto, que não faz jus ao brilhantismo intelectual dos que a utilizam). [...] A despeito das deficiências jurídico-institucionais vivenciadas no passado, refletindo o 
subdesenvolvimento socioeconômico do País, o Direito Constitucional brasileiro não começa com a Constituição de 1988 , tendo prestado relevantes contribuições sob a Constituição de 1824 e as republicanas de 1891 (basta lembrar a "teoria brasileira do habeas corpus"), 1934 e 1946. Não há, assim, que se falar em "pré-história constitucional brasileira", antes do advento do "neoconstitucionalismo" (RAMOS, 2010, p. 280).

$\mathrm{Na}$ concepção do pensamento do referido autor o direito está baseado em textos escritos e, por sua vez, não pode ser distorcido, isto é, ser alterado, mesmo na utilização da discricionariedade do intérprete. O subjetivismo que está dentro do ativismo judicial leva a uma ruptura com o sistema. Por outro lado, o voluntarismo sustenta que seria bom, no entanto, seguindo por esta corrente, ocorrer uma ruptura com o estado de Direito.

\begin{abstract}
Ao se fazer menção ao ativismo judicial, o que se está a referir é à ultrapassagem das linhas demarcatórias da função jurisdicional, em detrimento principalmente da função legislativa, mas, também, da função administrativa e, até mesmo, da função de governo. Não se trata do exercício desabrido da legiferação (ou de outra função não jurisdicional), que, aliás em circunstâncias bem delimitadas pode vir a ser deferido pela própria Constituição aos órgãos superiores do aparelho judiciário, e sim da descaracterização da função típica do Poder Judiciário, com incursão insidiosa sobre o núcleo essencial de funções constitucionalmente atribuídas a outros Poderes (RAMOS, 2010, p. 116).
\end{abstract}

$\mathrm{O}$ ativismo seria um defeito no exercício da função jurisdicional com sua ultrapassagem dos limites de sua atuação. Aqui haveria uma usurpação da função normativa, o que, por este motivo, acaba ingressando no campo da atuação política. O judiciário deve ser a palavra serena que mantém o equilíbrio entre as instituições:

\begin{abstract}
Nessa senda, a judicialização da política é provocada por causas políticas e jurídicas. Entre as causas políticas, além das já citadas, estão: a) o descrédito nas instâncias políticas tradicionais; b) 'a crise de representatividade, legitimidade e funcionalidade do Poder Legislativo'; e c) a morosidade das instâncias politicas tradicionais e 'sua incapacidade de realizar propósitos tão audaciosos de uma Constituição', fazendo com que o judiciário passe 'a ocupar espaços vazios' (FERNANDES, 2012, p. 54).
\end{abstract}

Ramos (2010) apresenta a questão envolvendo três pontos que precisam ser considerados ao analisar o fenômeno denominado judicialização da política, que são: a queda de credibilidade das esferas políticas de nosso país, as questões que tornam instável a atividade legislativa nacional e a morosidade do exercício das atividades executiva e legislativa no Brasil. 
Diante deste cenário, acaba-se por provocar uma procura pelo poder Judiciário em larga escala, dando surgimento para este fenômeno.

O professor em sua crítica, também pontua a respeito dos posicionamentos envolvendo os denominados pós-positivistas. Segundo o autor, estes seriam considerados antipositivistas, tendo em vista a falta de conexão com o pensamento de autores como Ronald Dworkin e Robert Alexy:

\begin{abstract}
$\mathrm{Na}$ verdade, os neoconstitucionalistas brasileiros são antipositivistas (e não póspositivistas), mas preferem dedicar um epitáfio ao positivismo jurídico do que se afirmar em combate com essa variante teórica, que continua extremamente influente no campo da Ciência do Direito (mera estratégia deslegitimadora, portanto, que não faz jus ao brilho intelectual dos que a utilizam). Nesse ponto, não tiveram a coragem e a capacidade teórica de Dworkin, que não apenas assume o seu antipositivismo, como, também, oferece-lhe uma alternativa teorética (o direito como integridade), da qual se pode (e, a meu ver, se deve) discordar, mas não se pode negar a consistência. Vislumbram-se no esboço propositivo neoconstitucionalista as tintas de um fluido moralismo jurídico, que "não despreza o direito posto", mas que o descarta, se necessário for, para que prevaleça a ordem objetiva de valores a que prestam vassalagem. Cuida-se sim de um jusnaturalismo mitigado, em que se propugna o distanciamento de categorias metafísicas ou do subjetivismo axiológico, para buscar na racionalidade argumentativa (à Alexy) ou na experiência histórica (à Dworkin) um mínimo de objetividade ética que permita a superação (em determinadas circunstâncias, apenas) da objetividade do direito legislado (RAMOS, 2010, p. 281).
\end{abstract}

Assim, o Judiciário é provocado a se manifestar em questões que competiriam aos Poderes Executivo e Legislativo que, diante de suas falhas, morosidade, falta de organização, e ineficiência, possibilitam uma aproximação do Direito com a Política:

\begin{abstract}
A judicialização da política ocorre porque os tribunais são chamados a se pronunciar onde o funcionamento do Legislativo e do Executivo mostra-se falhos, insuficientes ou insatisfatórios. Sob tais condições, ocorre certa aproximação entre Direito e Política e, em vários casos, torna-se mais difícil distinguir entre um 'direito' e um 'interesse político', sendo possível se caracterizar o desenvolvimento de uma 'política de direitos' (RAMOS, 2010, p. 281).
\end{abstract}

Segundo o autor, nasceria aqui uma "política de direitos", voltada ao atendimento das carências do cidadão por parte do Poder Judiciário que, servirá como salvaguardas das questões deficitárias do campo político nacional.

Perante a nossa pesquisa, surge a indagação: haveria no cenário brasileiro uma intervenção judicial das questões políticas? A questão que apresentamos encontra respaldo em estudo comparado feito por Valle (2009), que em uma de suas obras trata da experiência alemã, 
italiana e espanhola, no que concerne o ativismo judicial. Assim sendo, ressaltam-se as considerações da autora acerca da atitude alemã:

O que se percebe das espécies de provimento jurisdicional desenvolvido pela Corte alemã é uma sutil conciliação entre ativismo quanto ao conteúdo do texto constitucional, que busca, no entanto, caminhos de concretização no mundo da vida, que não desconsideram a indispensável intervenção das demais estruturas de poder, como estratégia - também de poder - para garantir o resultado de suas próprias decisões (VALLE, 2009, p. 28)

A experiência alemã encontrou na Constituição um caminho para conciliar as questões que envolvem o ativismo judicial. O intuito é meramente concretizador das carências da vida dos indivíduos que não encontram na política e sua respectiva atividade, uma solução para os seus mais variados tipos de problema. A autora em questão, também nos apresenta uma outra corrente doutrinária, que surgiu na Itália, denominada doutrina do direito vivente:

Além disso, há na Itália o desenvolvimento da doutrina do direito vivente, o qual serve de delimitação ao ativismo judicial, tendo em vista que "estabelece as fronteiras da discussão e orienta o objeto da própria atuação da Corte Constitucional (VALLE, 2009, p. 30).

A doutrina do direito vivente teria o condão de delimitar o fenômeno do ativismo judicial através de mecanismos de fixação de fronteiras da discussão judicial e a orientação do objeto da própria atuação da Corte Constitucional Italiana.

O Ativismo Judicial na Espanha aponta como o fenômeno se manifestou e desenvolveu-se naquele cenário, segundo Vanice do Valle:

[...] desenvolvimento jurisprudencial de técnicas e modalidades de provimento que permitem a concretização de atividades distintas da simples chancela de validade ou nulidade dos temas submetidos a controle. É no espaço da eventual baixa de densidade de normas constitucionais, já advertia Gómez Puente, que a atividade interpretativa encontrará maior liberdade de atuação; e justamente esses espaços proporcionaram na Espanha o desenvolvimento das sentenças interpretativas e aditivas, veículos da concretização do ativismo judicial (VALLE, 2009, p. 31).

Com o desenvolvimento de sentenças interpretativas e aditivas nasceriam os veículos do ativismo judicial espanhol, o que não foge às características do que tem ocorridos no cenário 
brasileiro. Aqui temos decisões da Corte Suprema e suas demais instâncias em alguns casos, que correspondem às características apontadas pelo modelo espanhol.

Sob este prisma, é possível perceber que há um elo entre o exercício de interpretação do texto para extração da norma a ser aplicada e, neste diapasão, os Magistrados proferem sentenças que vão além deste exercício de julgar onde as decisões tem natureza aditiva.

Vanice Regina Valle transmite a existência de uma dificuldade em identificar em quais momentos ocorre o ativismo através da atividade jurisdicional:

[...] o parâmetro utilizado para caracterizar uma decisão como ativismo ou não reside numa controvertida posição sobre qual é a correta leitura de um determinado dispositivo constitucional. Mais do que isso: não é a mera atividade de controle de constitucionalidade - consequentemente, o repúdio ao ato do poder legislativo - que permite a identificação do ativismo como traço marcante de um órgão jurisdicional, mas a reiteração dessa mesma conduta de desafio aos atos de outro poder, perante casos difíceis (VALLE, 2009, p. 21).

Fazendo um paralelo com o que ocorre na Espanha, trazemos partes de uma entrevista proferida por José Afonso da Silva perante a Ordem dos Advogado do Brasil (OAB, 2013). O mencionado Jurista além de abordar o referido assunto, dá sua posição sobre o fenômeno que se encontra presente no cenário do Poder Judiciário brasileiro.

Assim, ele expõe que em geral, entende-se que as interpretações criativas mais avançadas e controvertidas são aquelas que constitucionalizam novos direitos por via de construção e do ativismo judicial. Durante a palestra o referido jurista dá algumas noções de como surgiu o ativismo judicial:

O Judiciário brasileiro foi fértil na construção da chamada doutrina brasileira do habeas corpus, estendendo a proteção dos direitos pessoais líquidos e certos quando eles se destinavam a proteger apenas a liberdade pessoal de locomoção; dessa doutrina surgiu o mandado de segurança (OAB, 2013).

Em seguida, ele identifica o ativismo judicial como um exercício proativo de interpretação da Constituição por parte do Poder Judiciário. Segundo a entrevista, o aludido autor pontua que não é raro o avanço da atividade jurisdicional na solução de controvérsias por parte dos magistrados que, diante de um conflito, criam e constroem decisões com base na constituição meio de uma interpretação inovadora: 
[...] O ativismo judicial se caracteriza por um modo proativo de interpretação constitucional pelo Poder Judiciário, de modo que, não raro, os magistrados, na solução de controvérsias, vão além do caso concreto em julgamento e criam novas construções constitucionais [...]. O ativismo judicial é uma forma de interpretação constitucional criativa, que pode chegar até a constitucionalização de direitos, pelo que se pode dizer que se trata de uma forma especial de interpretação também construtiva $[\ldots](\mathrm{OAB}, 2013)$.

Outra reportagem de suma relevância que tratou das questões envolvendo o ativismo judicial foi realizada pelo Jornal Estado de São Paulo, de 20 de maio de 2013 (ESTADO, 2013), cujo título é "Ayres Britto diz que inércia do legislativo impõe 'experimentalismo' ao STF”, na qual temos a seguinte passagem:

\begin{abstract}
Nós estamos fazendo um experimentalismo decisório necessário, inevitável. Diante da inércia do legislador nós temos que nos apropriar conceitualmente de temas dificílimos, especialíssimos', comentou Britto, que ilustra com o julgamento de questões de caráter tributário como a análise de concessão de benefícios físcais. Com a sua atuação, a Corte se expõe a críticas 'de que está protagonizando ações normativas, de que tornou-se um Supremo ativista, substitutivo do Congresso Nacional, e portanto usurpador', aponta o ex-ministro (ESTADO, 2013).
\end{abstract}

Segundo o ex-ministro Carlos Ayres de Britto, há uma apropriação de temas sensíveis e de elevado grau de dificuldade que precisam ser apreciados diante da inércia do legislador brasileiro. Assim sendo, a consequência é a exposição do Supremo Tribunal Federal e em decorrência disso o crescimento no número de críticas seria um fato notório.

Na mesma linha de reportagem e tema abordado, segundo o Jornal Folha de São Paulo (FOLHA, 2013), em entrevista ocorrida por este periódico com o Ministro do Supremo Tribunal Federal Luís Roberto Barroso, em 18/12/1013, é possível compreender alguns pontos do debate acerca do ativismo judicial:

[Min. Barroso] O Congresso, pressionado pelas multidões que tinham ido para as ruas, estávamos no final de maio, quando eu estive lá, eu cheguei e naquele momento tinha uma reunião dos líderes discutindo: 'Nós vamos fazer a reforma política, não queremos nem plebiscito, que a presidente quer, nem Constituinte exclusiva, vai sair daqui'.

[Repórter do Jornal Folha de São Paulo] Não saiu nada.

[Min. Barroso] E logo que o povo saiu da rua essa agenda foi desarticulada. De modo que eu espero que a decisão do Supremo recoloque essa questão na agenda do Congresso. Mas eu acho que esta é uma competência política, decisão política tem que tomar quem tem voto. Agora, a inércia do Congresso traz riscos para a democracia. E proteger as regras da democracia é um papel do Supremo.

[Repórter do Jornal Folha de São Paulo] O sr. acha que o Congresso tem sido inerte por que razão nos últimos tempos? 
[Min. Barroso] Porque há muita dificuldade de se formar consensos, porque nós temos esse sistema político, esse sistema partidário, nós temos pessoas que, compreensivelmente -faz parte da natureza humana- não querem mudar a lógica do jogo que os ajudou a chegar lá (FOLHA, 2013).

Entre a apresentação de ideias, questionamentos e respostas é possível compreender alguns pontos importantes desta última entrevista citada pelo Ministro do Supremo Tribunal Federal Luís Roberto Barroso. O primeiro ponto abordado é a pressão das ruas, isto é a cobrança do cidadão brasileiro por uma reforma política que ensejou a pauta de questões envolvendo este tema perante a Corte Suprema do País.

O Supremo Tribunal Federal seria levado a se manifestar em matérias afetas à atividade legislativa que, deveria agir em prol de uma reforma política nacional de caráter reestruturante. No entanto, esta pauta ficou em segundo plano pela queda nas mobilizações populares de âmbito nacional.

O outro ponto é inércia legislativa que, segundo o entrevistado, encontra amparo nas dificuldades de formação e produção de um consenso legislativo sobre assuntos de relevância nacional. Sobre uma reforma política, os membros das casas legislativas têm muito mais interesse em manter privilégios e prerrogativas do que alterá-los em prol de um bem maior, o interesse público.

Ainda acerca do Ativismo Judicial, tem-se o pensamento de colaboração entre os Poderes da República que, serve como argumento favorável e amenizador das críticas que lhe são inerentes. Edinilson Donisete Machado em seu livro aborda este aspecto, que assim apresentamos:

A fase do atual desenvolvimento do Estado não comporta mais a discussão em torno da divisão dos poderes, como instrumentos estanque das funções, mas sim o princípio de que todas as funções não devem ser entregues em mãos de um só. Essa preocupação em se dividir as funções por compartimento estanque tinha sua razão de ser antes dos Estados de Direito, posto que a ausência da consagração de um princípio (como a tricotomia das funções hoje arraigada na maioria dos Estados) tinha como aliada sempre a usurpação das funções de um só indivíduo. Portanto, as funções devem estar uma em relação às outras como colaboradoras, até porque em cada uma delas existe a execução de funções análogas às outras. Aliás, como já salientado, é princípio constitucional, no qual se tem a harmonia e independência como fundamentos. Harmonia, como sinônimo de colaboração, de cordialidade necessária entre as funções. Independência, no sentido de não ser necessária a cada função a permissão da outra, para o exercício de suas competências (MACHADO, 2011, p. 104) 
A estrutura estatal, sua conjuntura com os dilemas sociais, o modo como o Estado é concebido na contemporaneidade seriam, segundo o autor, motivos para que as funções típicas dos três Poderes não sejam estanques.

Haveria assim um envolvimento participativo de um Poder sobre as lacunas da atividade de um outro Poder, não cabendo falar em usurpação de funções. O fundamento deste argumento se encontra na harmonia entre os Poderes da República que, devem agir em cooperação uns para com os outros.

Para Uadi Lammêgo Bulos (2012), em sua obra Constituição Federal Anotada é apresentado outro argumento que justificaria a possibilidade de Ativismo Judicial.

A interferência de um poder sobre o outro é apenas admissível para garantir direitos fundamentais, impedindo abusos e atentados contra a própria Constituição, caso contrário de nada adiantará a constitucionalização do princípio, porque ele existirá, apenas, nominalmente, sem qualquer relevância prática (BULOS, 2012, p. 67).

O autor em questão sustenta, que a admissibilidade de atuação proativa dos magistrados encontraria fundamento na garantia de direitos fundamentais que estejam sofrendo abusos e atentados e, as decisões a serem proferidas comportariam a respectiva interferência. Aqui temos uma série de argumentos que justificariam ou não o ativismo judicial, contudo, traremos na sequência o posicionamento de alguns estudiosos deste fenômeno que seriam contrários ou favoráveis a atuação do Poder Judiciário em completude a ausência da atividade Legislativa e Executiva do Estado.

\subsection{O Ativismo Judicial segundo André Ramos Tavares}

A questão da concretização dos direitos fundamentais está na contramão da atuação dos juízes de maneira irrestrita. As liberdades não geram custo pelo estado, e que este não atua positivamente na implementação, e assim o ativismo, o propositivismo do magistrado, tem seu lado positivo.

Em síntese, percebe-se que a ampliação do espaço "tradicional" do juiz constitucional (entre Judiciário e Tribunal Constitucional), na tutela da Constituição e sua supremacia (quer dizer, para além de um mero legislador negativo, na expressão cunhada por Kelsen) foi viabilizada, dentre outras ocorrências, pela abertura 
semântica das constituições, em sua contemplação principiológica do discurso dos direitos humanos, pela supremacia da Constituição, pela vinculação dos legislativos aos direitos fundamentais consagrados e, sobretudo, pela necessidade de retirar do espaço político certas opções (TAVARES, 2012, p. 66).

No entanto, na maioria dos casos concretos, os Magistrados são responsáveis pela implementação de direitos e garantias fundamentais. Para André Ramos Tavares (2012), isso consistiria em um avanço dentro de um espaço de segurança democrática.

[...] um avanço, dentro de um espaço de segurança democrática, da atuação do juiz constitucional, pressupõe uma consolidação dos métodos de trabalho dessa instância, máxime quando representada por um Tribunal Constitucional que exerça com monopólio e definitividade a defesa e implementação da Constituição (no âmbito de normas ambíguas e vagas como ocorre comumente com os direitos fundamentais) (TAVARES, 2012, p. 69).

Reforçando este argumento, temos uma passagem da obra de Conrado Hubner Mendes:

No lugar de justificar a revisão judicial com base na necessidade de proteção de direitos fundamentais, sustenta-se que a separação de poderes e seu potencial para a limitação da autoridade política propiciam uma base mais sólida para este arranjo [...] em vez de razão messiânica, tem-se uma razão prudencial. [...] a revisão judicial, além de um mero contrapeso ou 'veto a mais', legitima-se por seu potencial de enriquecer a qualidade argumentativa da democracia, por propiciar uma 'interlocução institucional (TAVARES, 2012, p. 70).

\subsection{O Ativismo Judicial segundo Ives Gandra da Silva Martins}

A resistência as vertentes do neoconstitucionalismo onde a constituição deve servir ao Poder Judiciário, ao legislador negativo. O século XXI poderia pertencer ao Poder Judiciário, mas por ser um poder técnico e não escolhido pelo povo, e seus predicados podem ser deixados de lado não podendo substituir os eleitos pelo povo (UOL, 2014).

De início, quero deixar claro que, nada obstante o protagonismo claro da Suprema Corte em diversas questões - a última, ao transformar-se em congresso nacional, editando norma sobre o aviso prévio, nada obstante a lei vigente à época ser inequivocamente constitucional (previa 30 dias que a lei suprema impõe como mínimo) -, não consigo encontrar, no texto supremo, qualquer norma que lhe permita tal auto-outorga de poderes legislativos, algo que jamais ocorreu no admirável passado do Pretório Excelso, autêntico guardião da Carta Magna e preservador de seu texto, mesmo quando nitidamente não lhe agradava (MENDES, 2008, p. 139). 
Montesquieu visualizou a tripartição dos poderes e trouxe isso ao plano da técnica ao plano prático, mas foi visualizada pelos atenienses nas obras de John Locke (UOL, 2014).

A judicialização da política não deve ocorrer, pois a Constituição Federal de 1988 possui mecanismos como no caso da ADI por omissão, no inciso 11 do artigo 49 que há o zelo pela invasão de competência devem ser utilizados (MARTINS, 2011).

A inconstitucionalidade por omissão aponta o dever do Congresso Nacional em criar a lei para suprir a omissão. No entanto, ao falar em direitos fundamentais e um campo amplo que dificulta uma limitação (UOL, 2014). O povo deve ir ao legislativo para exigir seus direitos e não do judiciário, que não o representa.

\subsection{O Ativismo Judicial segundo Christine Oliveira Peter da Silva}

O tema do Ativismo Judicial inspira os debates acerca do controle de constitucionalidade e da jurisdição constitucional.

O ativismo constitucional é toda ação que tenha como meta realizar a Constituição, ou mais especificamente, é o conjunto de ações, sempre complexo e descentralizado, de fazer valer as normas constitucionais jusfundamentais em todas as práticas de poder, seja pelo administrador público, seja pelo legislador, seja pelo juiz (PETER, 2015, p. 62).

O minimalismo e o ativismo são cada vez mais debatidos, e essa atuação consiste em um passo provocativo que chama atenção dos pesquisadores face a esse fato.

\footnotetext{
Assume-se, portanto, o ativismo judicial como parte integrante e inerente de ativismos legislativos e administrativos necessários para o exercício das competências constitucionalmente distribuídas entre os poderes. Seus limites, seus excessos e suas potencialidades devem ser enfrentados a partir da premissa de que somente os demais órgãos de poder têm poderes, no jogo democrático, para estabelecer os limites e conter eventuais excessos dessa prática que, se monopolizada por qualquer dos interlocutores, apresenta-se inadequada a qualquer versão de constitucionalismo (PETER, 2015, p. 77).
}

Qual seria o papel da suprema corte na vida política dos indivíduos e do Estado como um todo (CONJUR, 2014). Essa atuação não se sabe ainda se é contínua ou se chegará a um momento de estagnação. 


\title{
2.4 O Ativismo Judicial segundo André Reis Lacerda
}

O ativismo judicial necessariamente passa pela formação do magistrado, influências sociais e pessoas, e do estudo do direito. A opinião pública tem impacto nas decisões, pois tais decisões são reflexos daquilo que o povo quis (ASMEGO, 2012).

Em relação às posturas ativistas propriamente ditas, a par de toda a argumentação já referida, reforça-se apenas que sua legitimidade deveria estar condicionada a uma utilização extremamente parcimoniosa, apesar do aparente paradoxo desta afirmação. Ou seja, um ativismo moderado seria necessário em certos casos concretos, em momentos pontuais e excepcionais, em que os juízes, conscientes dos limites de suas capacidades institucionais, não pressupondo demasiadamente de uma atividade utópica e/ou 'salvadora', mesclariam tal prática atípica com uma recomendável postura de autocontenção judicial, para se evitar a substituição dos fóruns representativos essenciais à democracia (LACERDA, 2013, p. 132).

É preciso ter mais consciência nas decisões, além da coragem que não pode ser confundida com excesso. As audiências públicas tendem a dar legitimidade, como mecanismo processual, que são as decisões para fins de auxiliar como melhor decidir (ASMEGO, 2012).

\begin{abstract}
Para tanto, dentre outras, parte-se das seguintes premissas: i) a necessidade de atuação judicial em um ambiente marcado por sociedades plurais, complexas e que se ressentem da efetivação de direitos plasmados nas Constituições; ii) a 'judicialização' como um fenômeno encontrável na maioria dos países democráticos, em que a interpenetração entre direito e política tem ocasionado uma ocorrência de processos ao Judiciário em escala exponencial e sobre naturezas as mais variadas para as Cortes. Assim, sobretudo em países como o Brasil, em que se preceitua o princípio da inafastabilidade da apreciação judicial (art. $5^{\circ}$ XXXV da CFRB); iii) a conformação abrangente das Constituições, em regra de modelo prolixo e compromissório, com normas de natureza por vezes principiológica, reclama uma interpretação diferenciada do seu texto por parte do magistrado, até mesmo em função da realidade cambiante; iv) a Justiça Constitucional, considerada em si mesma, a despeito de não contar com uma legitimação pautada pelo voto popular, pretende-se compatível com o Estado Democrático de Direito (LACERDA, 2012, p. 132.)
\end{abstract}

Assim sendo, no plano da interpretação das normas e aplicação do Direito, através deste mecanismo processual as decisões tendem a ter mais solidez, mais consistência para efetivação de direitos.

\subsection{O Ativismo Judicial segundo Gilmar Ferreira Mendes}

A atuação do Poder Judiciário não exorbita o âmbito de suas competências quando faz a apreciação dos litígios. Quando o Judiciário não age e gera a insuficiência e quando o faz 
é ativismo, neste sentido, considera-se o exagero e a extrapolação de suas esferas de competência.

\begin{abstract}
No julgamento da $\mathrm{ADI} \mathrm{n}^{\mathrm{o}} 3.510$ (células-tronco embrionárias), assim se manifestou o Min. Gilmar Mendes em seu voto: O Supremo Tribunal Federal demonstra, com este julgamento, que pode, sim, ser uma Casa do povo, tal qual o parlamento. Um lugar onde os diversos anseios sociais e o pluralismo político, ético e religioso encontram guarida nos debates procedimental e argumentativamente organizados em normas previamente estabelecidas. As audiências públicas, nas quais são ouvidos os expertos sobre a matéria em debate, a intervenção dos amici curiae, com suas contribuições jurídica e socialmente relevantes, assim como a intervenção do Ministério Público, como representante de toda a sociedade perante o Tribunal, e das advocacias pública e privada, na defesa de seus interesses, fazem desta Corte também um espaço democrático. Um espaço aberto à reflexão e à argumentação jurídica e moral, com ampla repercussão na coletividade e nas instituições democráticas [...]. Portanto, é possível antever que o Supremo Tribunal Federal acabe por se livrar do vetusto dogma do legislador negativo e se alie à mais progressiva linha jurisprudencial das decisões interpretativas com eficácia aditiva, já adotadas pelas principais Cortes Constitucionais europeias. A assunção de uma atuação criativa pelo Tribunal poderá ser determinante para a solução de antigos problemas relacionados à inconstitucionalidade por omissão, que muitas vezes causa entraves para a efetivação de direitos e garantias fundamentais assegurados pelo texto constitucional (STF, 2010).
\end{abstract}

Sustenta-se que o Judiciário não aplica o Direito de maneira adequada e por sua vez fugindo do que prevê a Constituição. Esse assunto surge em detrimento das diversas opiniões e pensamentos de cunho ideológico quando se coloca uma decisão em debate, em cheque e questionamento acerca dos seus acertos (OS CONSTITUCIONALISTAS, 2014).

\title{
2.6 O Ativismo Judicial segundo Ricardo Lewandowski
}

O Ativismo Judicial ou protagonismo judicial decorre dos inúmeros litígios que existem no Brasil. O povo na busca da informação está interligado com a Justiça. Essa expressão aponta que o Judiciário está agindo de ofício (POLÍTICA REAL, 2014). Com a existência dos princípios as decisões estão vinculadas a aplicação destes.

O Judiciário está ampliando o espaço de atuação sem invadir a esfera de competência assegurando assim a defesa dos direitos e garantias fundamentais. Os magistrados não podem se deixar seduzir pelo impacto da mídia. O Mundo moderno rompeu com a ideia da tripartição original de Montesquieu, onde o juiz era a boca da lei (POLÍTICA REAL, 2014). 
A força dos juízes é muito mais criadora e atuante, desde que não se invada as esferas de competência dos demais poderes. Os Juízes devem ser recatados, mas estudiosos na compreensão do Mundo complexo (POLÍTICA REAL, 2014).

\subsection{O Ativismo Judicial segundo Clemerson Merlin Cleve}

O Ativismo Judicial nem sempre pode ser tomado como uma medida adequada, o Judiciário precisa ser deferente em termos do que prevê a Constituição (CLEVE, 2014).

A estranheza está atrelada a judicialização em função da gama de competências do Poder Judiciário e, ao mesmo tempo, os direitos e garantias fundamentais o Judiciário acaba recebendo um número enorme de demandas, onde este Poder deve dizer o direito (CLEVE, 2014). Atualmente em razão do constitucionalismo e tendo em vista que o Judiciário é um Poder.

\subsection{O Ativismo Judicial segundo Dalmo de Abreu Dallari}

Universalização de Direitos Humanos sofre implicações em detrimento do Judiciário. Aplicação de princípios e valores estrangeiros de outros judiciários pelo judiciário interno.

A influência da jurisprudência internacional independe de um tratados entre Estados, basta que o magistrado nacional tome conhecimento e adeque ao caso concreto. $\mathrm{O}$ novo constitucionalismo visa a legitimação e a efetividade da constituição e os direitos em seu teor. (DALLARI, 2010).

A lei não é necessária para efetivá-la pois as normas fundamentais têm aplicabilidade imediata. O crescimento da noção de direito e a luta por efetivação deles tem aumentado. Pode se dizer que isso contribuiu em uma parcela menor na morosidade do Judiciário que tende atender as demandas do povo.

\section{CONSIDERAÇÕES FINAIS}

Para aqueles que defendem o fenômeno neoconstitucionalismo, ocorreu um desenvolvimento significativo do ativismo judicial, que em linhas gerais consiste na função 
jurisdicional possuir aspectos de função normativa, o que atribuiria ao Judiciário capacidade normativa de caráter supletivo.

Partindo de uma premissa basilar, isto é, das funções típicas do Poder Judiciário conferida pela Constituição Federal de 1988, é possível constatar que a atividade julgadora e a função decisória constituem ação primordial deste Poder.

No entanto, para alguns estudiosos do Direito Nacional e Estrangeiro, em um Estado que se estabelece por bases democráticas, se faz necessário, que as atividades de um Poder não se limitem apenas a Julgar, no caso do Poder aqui apontado, existindo assim funções que embora não preponderante, auxiliam com a harmonia dos Poderes e com o bem estar social.

A atividade do Judiciário, em alguns momentos, pode ser invocada para suprir a omissão do Parlamento, fomentar a prática de políticas públicas e, proteger direitos e garantias fundamentais das minorias, como ocorreu em casos cuja o tema eram: o reconhecimento da união homoafetiva, tutela e demarcação das terras indígenas, entre outros, tem sido de suma importância para a democratização do processo constitucional.

A respeito dos déficits do Poder Legislativo, o Poder Judiciário pode adotar três formas de julgamento. A primeira, denominada non liquit, em que o magistrado só julga com base na legislação e, no caso concreto em que esta não exista, não decide, por não haver direito positivado.

Outra forma é a suspensiva, onde o Judiciário conhece do pedido, notifica o órgão e legislador omissos e, aguarda a inovação legislativa. Por fim, a forma integrativa ou concretista; esta teoria se baseia na corrente do "ativismo judicial" que prega que a missão do Judiciário é a solução dos conflitos, tornando efetivo o direito existente.

Os críticos do fenômeno do Ativismo Judicial reforçam em seus discursos que não se pode permitir que o Judiciário esgote a atividade típica do Poder Legislativo e não se envolva em questões de competência das esferas da Administração Pública.

Temos em mente que todo e qualquer excesso deve ser repudiado, uma vez que, isso ofenderia e comprometeria a democracia do País. O Poder Judiciário não deve esvaziar as ações que competem primordialmente ao parlamento ou do executivo. 
Entretanto, é perceptível que os defensores do ativismo judicial surgem com discurso em prol da efetivação de direitos que ainda não alcançaram seu espaço na ordem jurídica constitucional.

Há que se falar também, no ativismo em detrimento da implementação de políticas públicas e na defesa dos interesses da sociedade, quando não amparados pela lei em sentido estrito.

Existem instrumentos que contribuem para ao advento do ativismo judicial. $\mathrm{O}$ Mandado de Injunção é cabível quando o direito constitucional se mostre inviabilizado por falta de norma regulamentadora, ou seja, a norma constitucional é de eficácia limitada e necessita de outra norma para produzir todos os seus efeitos.

Assim a omissão pode ser suprida pelo Poder Judiciário. Outro exemplo significativo são as normas constitucionais de eficácia limitada que são capazes de produzir efeitos no mundo jurídico, ainda que a norma integradora não exista, por ora.

Além disso, podemos mencionar a norma posterior que revoga a anterior no caso de não recepção, isto é a norma limitada condiciona a atuação legislativa.

A atividade legislativa só poderá ser traçada em consonância com a norma de eficácia limitada, não podendo ser editada nenhuma norma legislativa que conflite com a norma limitada, sob pena de ser inconstitucional.

Este fenômeno é ainda mais intenso nos sistemas normativos abertos, que contém mais princípios do que regras, ampliando a capacidade de interpretação dos magistrados. A consequência deste fenômeno é que a norma passa a ser o resultado da interpretação e não o seu pressuposto. No neoconstitucionalismo, os juízes aplicam diretamente a constituição, sem ter a lei como intermediária.

Neste contexto, houve o desenvolvimento do fenômeno da judicialização da política e politização do Judiciário, que permitem ao Judiciário interferir dentro de certos limites, nos negócios da Administração Pública.

Isto fica evidente no campo do controle de constitucionalidade concentrado e difuso, como por exemplo, no julgamento de ações como Ação Popular e Ação Civil Pública, em que o juiz define o conteúdo de princípios que vinculam a administração como princípio da moralidade e da eficiência. 
Assim sendo, coibindo os excessos que podem surgir, o ativismo judicial tem por características de contribuição para a democratização do País, a melhoria da prestação jurisdicional e a efetivação plena de direitos e garantias da ordem jurídica constitucional.

\section{REFERÊNCIAS BIBLIOGRÁFICAS}

ASMEGO, 2012, Entrevista. Disponível em: http://asmego.org.br/2012/10/25/juiz-andre-reislacerda-coordenador-executivo-do-xi-congresso-goiano-da-magistratura-fala-sobre-ativismojudicial-tema-central-do-evento-promovido-pela-associacao-dos-magistrados-do-estado-degoias/. Acesso em: 01 de fevereiro de 2014.

BULOS, Uadi Lammêgo. Constituição Federal Anotada. 10ª ed., at. e ref. São Paulo:. Editora Saravia.2012.

CAPPELLETTI, Mauro. Repudiando Montesquieu? A expansão e a legitimidade da “justiça constitucional”. Revista do Tribunal Regional Federal da $4^{\text {a }}$ Região. - Vol. 1, n. 1, (jan./mar. 1990). - Porto Alegre: O Tribunal, 1990 - v. - Trimestral. ISSN 0103-6599. Tradução de Fernando Sá.

CLEVE, 2014, Fala. Disponível em: http://www.clemersoncleve.adv.br/prof-clemersonmerlin-cleve-fala-sobre-o-ativismo-judicial-e-seus-reflexos-no-campo-constitucional/. Acesso em: 01 de fevereiro de 2014.

CONJUR. 2014, Observatório. Disponível em: http://www.conjur.com.br/2014-dez20/observatorio-constitucional-ativismos-sao-necessarios-estado-direitos-fundamentais.

Acesso em: 01 de fevereiro de 2014.

DALLARI, Dalmo de Abreu. A constituição na vida dos povos: da idade média ao século XXI. São Paulo:Saraiva, 2010.

ESTADO, 2013, Notícias. Disponível em: https://politica.estadao.com.br/noticias/geral,ayres-britto-diz-que-inercia-do-legislativoimpoe-experimentalismo-ao-stf,1033757. Acesso em: 01 de fevereiro de 2015.

FERNANDES, Ricardo Vieira de Carvalho. Ativismo Judicial: Por Uma Delimitação Conceitual À Brasileira, Apud Confluências, Revista Interdisciplinar de Sociologia e Direito, v. 12, n.2, 2012, UFF: Rio de Janeiro.

FOLHA, 2013, Entrevista. Disponível em: http:/www1.folha.uol.com.br/.../1388727entrevista-com-luis-... Acesso em: 14 de janeiro de 2014.

LACERDA, André Reis. Separação dinâmica das funções estatais: análise de um ativismo judicial moderado na perspectiva de uma leitura dialógica na Constituição brasileira de 1988 impediente de configuração de instâncias hegemônicas. Revista do Instituto do Direito Brasileiro Ano 2 (2013), nº 6, 5045-5108 / http://www.idb-fdul.com/ ISSN: 2182-7567 50635064. Acesso em 01 de fevereiro de 2014. 
MACHADO, Edmilson Donisete. Ativismo Judicial. São Paulo: Letras Jurídicas. 2011.

MARTINS, Ives Gandra da Silva. O Ativismo Judicial e a Ordem Constitucional. Revista Brasileira de Direito Constitucional - RBDC n. 18 - jul./dez. 2011.

MENDES, Conrado Hubner. Controle de Constitucionalidade e democracia. Campus Elsevier: São Paulo, 2008.

OAB, 2013. Notícia. Disponível em: http://www.oab.org.br/noticia/25758/jose-afonso-dasilva-aborda-o-ativismo-judicial-em-seminario-da-oab. Acesso em: 01 de fevereiro de 2015.

OS CONSTITUCIONALISTAS. 2014. Conversar. Disponível em: http://www.osconstitucionalistas.com.br/conversas-academicas-gilmar-mendes-e-ajurisdicao-constitucional-ii. Acesso em: 01 de fevereiro de 2014.

PETER, Christine Oliveira. Do ativismo judicial ao ativismo constitucional no Estado de direitos fundamentais. Revista Brasileira de Políticas Públicas, Brasília, v. 5, Número Especial, 2015.

POLÍTICA REAL. 2014. Blogs. Blpgs.http://www.politicareal.com.br/blogs/brasilia-pormauro-sampaio/538348/com-lewandowski-ativismo-judicial-so-em-caraterexcepcional\#.VPDJjPnF90o Acesso em 01 de fevereiro de 2014.

RAMOS, Elival da Silva. Ativismo judicial: parâmetros dogmáticos. São Paulo: Saraiva, 2010.

REVISTA JURÍDICA. 2014. Advogados. Disponível em: lhttp://revistavisaojuridica.uol.com.br/advogados-leis-jurisprudencia/63/ativismo-judicial-dostf-225388-1.asp. Acesso em: 01 de fevereiro de 2014.

STF. Pleno. Julgamento. ADI no 3.510/DF. Rel. Min. Ayres Britto, julgamento em 29-052008, DJ de 28-05- 2010.

TAVARES, André Ramos. Paradigmas do judicialismo constitucional. São Paulo: Saraiva, 2012.

VALLE, Vanice Regina Lírio do, Ativismo Jurisdicional e o Supremo Tribunal Federal. São Paulo: Juruá, 2009. 